\title{
Profile and Development Model of Micro, Small and Medium Enterprises (MSMEs) in Jambi Province (Through Superior Commodities Approach)
}

\section{Zulfanetti $^{1}$, Ade Octavia ${ }^{2}$, Erida ${ }^{3}$}

${ }^{1}$ Faculty of Economic and Business, University of Jambi, Jambi and Indonesia,

$\square$ (e-mail) zulfa netti@unja.ac.id

${ }^{2}$ Faculty of Economic and Business, University of Jambi, Jambi and Indonesia,

$\varangle$ (e-mail) octavia@unja.ac.id

${ }^{3}$ Faculty of Economic and Business, University of Jambi, Jambi and Indonesia,

$\triangle$ (e-mail) erida.ida@unja.ac.id

\begin{abstract}
This study aims to analyze (1). the development of Value of Production, Credit, Number of Business, Labor and Asset of MSMEs; (2). the factors that influence the value of production of MSMEs; (3). the superior sectors of MSMEs; (4). superior commodity of MSMEs spread in Regency / City of Jambi Province. The study design was used cross sectional. The study was conducted in Jambi Province. Overall research time of 2 years. For the first year, an analysis of the growth and growth of MSMEs in Jambi Province, an analysis of the factors that influence the value of MSMEs production, the analysis of the superior sectors and commodities. While the second year is done an analysis of MSMEs profile, identification of strength, weakness, opportunity, and threat (SWOT) from MSMEs. Data analysis using multiple linear regression with panel data. The results showed that the development of SMEs in the period 2010-2015 seen from the value of production, credit, business, absorption of labor and assets experienced an increasing trend. Factors that significantly affect the value of MSMEs production are credits and assets. The result of LQ analysis shows that the sector which is the base sector (LQ> 1) based on the use of labor varies among the regencies / cities in Jambi Province. Analysis of the superior commodities shows that there are 28 superior commodities in agriculture sector from food crops, horticulture, plantation, animal husbandry, marine and fishery. Furthermore, for the second year, the formulation of sustainable MSMEs development model will be developed. MSMEs in the digital era must make changes management, mindset, and action to stay in the business world.
\end{abstract}

Keywords: MSMEs, Superior sector, and Superior commodity

\section{Introduction}

The important role of Micro, Small and Medium Enterprises (MSMEs) in Indonesia is increasingly felt in the process of national economic development. Initially, the existence of MSMEs was considered an important source of job creation and the main driving force of local economic development in rural areas. However, in the current and future era of globalization, the role of MSMEs existence is increasingly important as one source of foreign exchange of non-oil and gas exports of Indonesia, (Tambunan, 2012).

MSME's role has also been actualized in times of crisis to date. During the economic crisis until now, the existence of MSMEs is able to be the main driving factor of Indonesian economy. Especially when the crisis of investment activity and government spending is very limited, then at that time the role of MSMEs as a form of people's economy is very large. Furthermore, in terms of contribution to GRDP is only $56.7 \%$ and non-oil exports only $15 \%$. However, MSMEs still contribute $99 \%$ in the number of business actors in Indonesia, and has a share of 99.6\% in employment (BPS, 2013). 
MSMEs are business activities that are able to expand employment and play a role in the process of increasing public income, even during the crisis of MSMEs known to encourage economic growth. The government encourages micro, small and medium enterprises (MSMEs) to continue to grow so that it can absorb more labor. MSMEs are expected to play a role in reducing unemployment. Minister of Cooperatives and SMEs Syarif Hasan (Depkop, 2012) revealed, the growth of MSMEs in Indonesia increased rapidly last two years. If two years ago the number of MSMEs ranged from 52.8 million business units, in 2011 has increased to 55.2 million units. The increasing number of MSMEs is expected to be proportional to the absorption of manpower. Nationally the average MSMES can absorb 3-5 workers. With the addition of about 3 million units of MSMES, in the last two years, the amount of worker absorbed increased by 15 million people. Seeing the role of MSMEs that are so strategic, MSMEs can realize one of the Millennium Development Goals of poverty alleviation and hunger.

According to information and data from the Office of Cooperatives and SMEs Jambi Province (2015) known that in 2014 MSMES amounted to 81,959 units, absorbing labor as much as 154,529 people. Total assets reach Rp. 176,695,369,438.73 and turnover amounted to Rp. 598.415.171.235,63. When compared with the year 2010, the average growth during the five years of $6.047 \%$ of the number of MSMEs in Jambi Province. The growth of total employment, assets and turnover in the same period are $10.862 \%, 8.199 \%$ and $9.006 \%$ respectively. The growth of MSMEs shows that MSMEs play a significant role in increasing the growth rate of real sector in Jambi Province. Muaro Jambi Regency has the highest number of MSMEs, followed by Jambi city, Sungai Penuh city, Tanjung Jabung Barat regency and Tanjung Timur regency.

Given the strategic role of MSMEs it is necessary to empower MSMEs in order to grow and develop into a tough and independent business. In Law No.20 / 2008 on MSMEs, it is defined that empowerment is an effort by the Government, Regional Government, Business, and Society synergistically towards MSMEs. Empowerment can be done if potential, problems, opportunities and challenges faced by MSMES as a whole is known.

MSMEs in the digital era must make changes management, mindset, and action to stay in the business world. Advances in information technology have changed the business order through disruption, affecting the pattern and behavior of production and consumption of society. Disruption ultimately creates a new world of digital marketplace that becomes a new event for business actors including MSMEs.

Research Purposes

1. Analyzing the development of Production Value, Credit, Number of Business, Labor and Asset of MSMEs in Regency / City in Jambi Province.

2. Analyzing the factors that affect the value of production of MSMEs in the Regency / City of Jambi Province.

3. Analyzing the superior sectors of SMEs in the Regency / City in Jambi Province.

4. Analyze the superior commodities of MSMEs scattered in the Regency / City in Jambi Province.

\section{Methods}

This study used survey methods, by collecting information from respondents who are expected to represent the entire population. Information collected from respondents in this survey method is using list of prepared questionnaires (Nazir, 2005). The collection of information from respondents is also done by means of Focus Group Discussion (FGD) and in-depth interviews with keypersons.

The data in this research consist of secondary data and primary data. Secondary data is obtained from offices and institutions related to MSMEs in Jambi Province, such as Department of Cooperative 
and MSMEs, Department of Industry and Commerce, Central Bureau of Statistics, Department of Planning, Indonesia Bank, and other related institutions.

The primary data collected through a survey of MSMEs. The population is all MSMEs spread in 11 regency / city in Province. Samples are MSMEs that have a superior commodity, the size of the sample is determined purposively based on the MSME profile.

To answer the first problem, descriptive analysis is used, which analyzing development and contribution of MSMEs to GRDP and absorption of labor in last five years at 11 regency / city in Jambi Province.

To answer the second problem, multiple linear regression analysis is used with panel data, ie the last five years data in 11 regencies / city in Jambi Province. Model specifications in accordance with the formulation of research problems are shown by the following equation:

$\log$ GRDPMit = a 0 + a $1 \log$ KREMit + a $2 \log$ PTKMit + a $3 \operatorname{logJUSMit~+~a4logASTM~+~eiit~}$

where:

GRDPM = Gross Domestic Product of MSMEs

KREM = MSMEs Credit

JUSM = Number of MSMEs Business Units

PTKM $=$ Total Absorption of MSMEs Business Workers

ASTM $=$ MSMEs Assets

$\mathrm{i}=$ Regency / City in Jambi Province (11)

$\mathrm{t}=$ Time Period $2010-2015$

To answer the third problem used Location Qoutient Analysis (LQ), which determines the superior commodities of MSMEs in 11 regency / city with the following formula:

$\mathrm{LQ}=\frac{E i j / E j}{E i n / E n}$

Where:

$\mathrm{LQ}=$ Location Qoutient Coefficient

Eij $=$ GRDP Commodities $\mathrm{i}$ in the study area

$\mathrm{Ej}=$ Total GRDP Commodities $\mathrm{i}$ in the study area

Ein $=$ GRDP Commodities $\mathrm{i}$ in reference region

En $=$ Total GRDP Commodities $\mathrm{i}$ in reference region

To answer the fourth problem of identifying superior commodities in the regency / city of Jambi Province, the method of analyzing the relative economy potential of regional is used. There are several analytical tools that can be used to determine the relative economic potential of a region such as Location Quotien (LQ) analysis and Shift Share analysis. The combination of both LQ and Shift Share analysis will provide superior competitive commodities in Jambi Province's regency / city. 


\section{Results}

A. MSMEs Development and Growth during 2010 - 2015 in Jambi Province

Table 1 MSMEs Development during 2010 - 2015 in Jambi Province

\begin{tabular}{rrrrrrr}
\hline NO. YEAR & GRDP MSMEs & $\begin{array}{c}\text { CREDIT } \\
\text { MSMEs }\end{array}$ & $\begin{array}{c}\text { Number } \\
\text { of MSMEs }\end{array}$ & $\begin{array}{c}\text { MSMEs } \\
\text { Employnment }\end{array}$ & MSMEs ASSET \\
\hline 1 & 2010 & $436.499 .968 .788,00$ & $38.817,88$ & $65.240,00$ & $104.042,00$ & $132.026 .748 .151,20$ \\
2 & 2011 & $441.039 .568 .463,40$ & $23.538,84$ & $67.825,00$ & $110.538,00$ & $133.399 .826 .331,97$ \\
3 & 2012 & $445.626 .379 .975,41$ & $29.457,17$ & $79.119,00$ & $119.932,00$ & $134.787 .184 .525,83$ \\
4 & 2013 & $592.255 .711 .832,57$ & $33.910,89$ & $81.552,00$ & $153.761,00$ & $174.478 .441 .761,89$ \\
5 & 2014 & $598.415 .171 .235,63$ & $36.232,47$ & $81.959,00$ & $154.529,00$ & $176.695 .369 .438,73$ \\
6 & 2015 & $2.461 .414 .337 .254,00$ & $39.299,37$ & $81.979,00$ & $168.288,00$ & $1.397 .682 .458 .584,00$ \\
\hline
\end{tabular}

Source: Cooperative institution and Small business enterprises, province Jambi, 2017

Table 2 MSMEs Growth during 2010 - 2015 in Jambi Province

\begin{tabular}{rrrrrrr}
\hline NO. YEAR & GRDP MSMEs & $\begin{array}{c}\text { CREDIT } \\
\text { MSMEs }\end{array}$ & $\begin{array}{c}\text { Number } \\
\text { of MSMEs }\end{array}$ & $\begin{array}{c}\text { MSMEs } \\
\text { Employnment }\end{array}$ & MSMEs ASSET \\
\hline 1 & 2011 & 1,04 & $-39,36$ & 3,96 & 6,24 & 1,04 \\
2 & 2012 & 1,04 & 25,14 & 16,65 & 8,50 & 1,04 \\
3 & 2013 & 32,90 & 15,12 & 3,08 & 28,21 & 29,45 \\
4 & 2014 & 1,04 & 6,85 & 0,50 & 0,50 & 1,27 \\
5 & 2015 & 311,32 & 8,46 & 0,02 & 8,90 & 691,01 \\
\multicolumn{2}{l}{ Rata-rata } & 69,47 & 3,24 & 4,84 & 10,47 & 144,76 \\
\hline
\end{tabular}

Source: Cooperative institution and Small business enterprises, province Jambi, 2017

\section{B. Factors Affecting The Value of MSMes Production in Jambi Province}

After estimating these three approaches, we will choose which model is more suitable than the three estimators so that the best estimator will be obtained (unbiased). In this research, two model testing methods are used to get the best model that is F Test (Chow Test) to choose the best model between PLS method and fixed effect method and Hausman test to choose the best model between fixed effect method and random effects method. 
Table 3 Estimation Method: Random Effect

Correlated Random Effects - Hausman Test

Pool: Untitled

Test cross-section random effects

\begin{tabular}{lrrr}
\hline \hline Test Summary & Chi-Sq. Statistic & Chi-Sq. d.f. & Prob. \\
\hline \hline Cross-section random & 4.662519 & 4 & 0.3237 \\
\hline
\end{tabular}

Cross-section random effects test comparisons:

\begin{tabular}{crrrr} 
Variable & Fixed & Random & Var(Diff.) & Prob. \\
\hline \hline LNKRED? & 0.205681 & 0.224757 & 0.010096 & 0.8494 \\
LNJUS? & -0.472470 & -0.271574 & 0.069353 & 0.4456 \\
LNTK? & 0.614785 & 0.342535 & 0.062514 & 0.2762 \\
LNASET? & 0.919371 & 0.922154 & 0.000332 & 0.8786 \\
\hline \hline
\end{tabular}

Cross-section random effects test equation:

Dependent Variable: LNGRDP?

Method: Panel Least Squares

Date: 10/08/17 Time: 18:54

Sample: 20102015

Included observations: 6

Cross-sections included: 11

Total pool (balanced) observations: 66

\begin{tabular}{crrrr}
\hline \hline Variable & Coefficient & Std. Error & t-Statistic & Prob. \\
\hline \hline C & -1.279693 & 1.543221 & -0.829235 & 0.4108 \\
LNKRED? & 0.205681 & 0.138632 & 1.483644 & 0.1441 \\
LNJUS? & -0.472470 & 0.430835 & -1.096640 & 0.2780 \\
LNTK? & 0.614785 & 0.406040 & 1.514099 & 0.1362 \\
LNASET? & 0.919371 & 0.045462 & 20.22272 & 0.0000 \\
\hline \hline
\end{tabular}

Effects Specification

Cross-section fixed (dummy variables)

\begin{tabular}{lrll}
\hline \hline R-squared & 0.974517 & Mean dependent var & 23.23420 \\
Adjusted R-squared & 0.967522 & S.D. dependent var & 5.236870 \\
S.E. of regression & 0.943770 & Akaike info criterion & 2.918848 \\
Sum squared resid & 45.42580 & Schwarz criterion & 3.416497 \\
Log likelihood & -81.32198 & Hannan-Quinn criter. & 3.115493 \\
F-statistic & 139.3112 & Durbin-Watson stat & 1.447677 \\
Prob(F-statistic) & 0.000000 & & \\
\hline \hline
\end{tabular}




\section{Interpretation of Regression Result with Best Model (Random Effect)}

Based on the result of model selection test that has determined the Random Effect model as the best model, the causality relationship between the variables formed according to the best model estimator from Random Effect regression analysis in the table can be represented by the following equation:

Based on the results of model selection tests that have set the Fixed Effect model as the best model, then the causality relationship between variables formed according to the best model estimator Random Effect regression analysis results in the above table, can be represented by the following equation:

LNPDRB it $=-0,90266+0,2248$ LNKRED $_{\text {it }}-0,2716$ LNJUS $_{\text {it }}+0,3425$ LNTK $_{\text {it }}+0,9221$ LNASET $_{\text {it }}+$ $\varepsilon_{\text {it }}$

a. Constant value of -0.90266 means that if all variables are constant then the production value (GRDP) of MSME is equal to -0.90266 .

b. LNKRED variable coefficient value is 0.2248 means that if the variable LNJUS, LNTK and LNASET constant then every $1 \%$ increase in credit value then the value of MSMES production will experience an increase of $22.48 \%$.

c. LNJUS variable coefficient value is 0.2716 means that if the LNKRED, LNTK and LNASET variables are constant then every $1 \%$ decrease in the value of the number of business then the value of MSMES production will increase by $27.16 \%$.

d. LNTK variable coefficient value is 0.3425 means that if the variable LNKRED, LNJUS and LNASET constant then every $1 \%$ increase in the amount of labor then the value of MSMES production will experience an increase of $34.25 \%$.

e. LNASET variable coefficient value is 0.9921 means that if the LNKRED, LNTK and LNJUS variables are constant then every $1 \%$ increase the value of total assets then the value of MSMES production will increase by $92.21 \%$.

To test the hypothesis is done three stages, namely:

a. Simultaneous Significance Test (F-test)

Based on the results of multiple linear regression in the table above, it is known that the value of Fhitung is equal to 369,7412 and the value of Ftabel is 2.53 (at N1 = 4 and N2 =61), so Fcount> Ftable so that H0 is rejected, which means free variable Credit, Number of Business, Labor and Asset simultaneously have influence to GRDP of Processing Industry Sector, with significance value equal to $0,0000<$.

b. Partial Significance Test (t-test)

The $t$ test ( $t$-test) is performed to determine whether the independent variables entered into the model have an individual (partial) effect on the dependent variable. Partial significance test is done by looking at the influence of individual independent variable to dependent variable that is influence

each variable of Capital Expenditure, Investment and Labor to GRDP of Processing Industry Sector. The specified test criteria is if tcount $>$ ttable then $\mathrm{HO}$ is rejected and if $\mathrm{t}<\mathrm{ttable}$ then $\mathrm{HO}$ is accepted.

Based on the results of multiple linear regression in the table above obtained the following information:

1) Credit variable (LNKRED) is positive on $t$-count $=2.3532$ and $t$-table $=2.132$ so thitung $>$ ttable, $\mathrm{H} 0$ is rejected, which means that Credit variable (LNKRED) has a positive contribution or has a direct relationship with the production value of MSMES (LNGRDP). The probability value of $0.0219<$ means that individual Credit variables have a significant influence on the value of prosduksi (LNGRDP) MSMEs.

2) Variable Number of Business (LNJUS) is negative with $\mathrm{t}$-count $=\mathrm{I}-0.7964 \mathrm{I}$ and $\mathrm{t}$-table $=2,132$ so tcount <ttable, H0 is accepted, which means that the variable Number of Enterprises (LNJUS) has no negative relationship with value production (LNGRDP) of MSMES. Probability value of $0.4289>$ means that the variable Number of Business (LNJUS) individually does not have a significant influence on the production value (LNGRDP) SMEs. 
3) Labor Variables (LNTK) is positive on $\mathrm{t}$-count $=1.0707$ and $\mathrm{t}$-table $=2.132$ so $\mathrm{t}$ count $<$ ttabel, H0 accept, which means that the variable Labor (LNTK) has a positive contribution or have a unidirectional relationship with the value production (LNGRDP) of MSME, but probability value of $0.2885>$ means that the variable of Labor (LNTK) individually does not have significant influence to production value (LNGRDP) of MSMES.

4) Asset Variable (LNASET) is positive on $t$-count $=22,1390$ and $t$-table $=2.132$ so thitung $>$ ttable, $\mathrm{H} 0$ is rejected, which means that the ASET variable (LNASET) has a positive contribution or has a direct relationship with the production value LNGRDP) MSMES, probabilita value of 0.0000 $<$ means that the variable ASET (LNASET) individually has a significant influence on the production value (LNGRDP) SMEs.

c. Coefficient of Determination (R-Squared / $\mathrm{R}^{2}$ )

The hypothesis in this research has been accepted that the independent variables of Credit, Number of Business, Manpower, and Asset, simultaneously have significant influence to production value (LNGRDP) of MSMES. Because the research variables consist of more than two variables, the feasibility can be seen from the R-squared and Adjusted R-squared values. The R-squared and Adjusted R-squared values obtained from the data processing were 0.9604 and 0.9578 .

The value of $\mathrm{R}^{2}$ of 0.9604 means that the relationship between dependent variable of production value (LNGRDP) of MSMES with independent variable of Credit, Number of Business, Labor, and Assets, is very strong (close to $100 \%$ ) that is equal to 96,04\%. The value of Adjusted R-squared of 0.9578 shows that $95,78 \%$ of production value variable (LNGRDP) of MSME can be explained by Credit variable, Number of Business, Labor and Asset, while the rest equal to 4,22\% influenced by other variable which is not mentioned in this study.

\section{Analysis of MSMEs Superior Sector in Regency / City in Jambi Province}

Table 4. LQ Analysis of Superior Sector

\begin{tabular}{|c|c|c|c|c|c|c|c|c|c|c|c|c|}
\hline \multirow[b]{2}{*}{ No. } & \multirow[b]{2}{*}{ Economic Sector } & \multicolumn{11}{|c|}{ Regency / City } \\
\hline & & Kerinci & Merangin & Sarolangun & Batanghari & $\begin{array}{l}\text { Muaro } \\
\text { Jambi }\end{array}$ & $\begin{array}{l}\text { Tanjab } \\
\text { Timur }\end{array}$ & $\begin{array}{c}\text { Tanjab } \\
\text { Barat }\end{array}$ & Tebo & Bungo & $\begin{array}{c}\text { Kota } \\
\text { Jambi }\end{array}$ & $\begin{array}{l}\text { Sungai } \\
\text { penuh }\end{array}$ \\
\hline \multirow[t]{2}{*}{1} & $\begin{array}{l}\text { Water, Severage, } \\
\text { and Waste }\end{array}$ & & & & & & & & & & & \\
\hline & Management & 0,42 & 0,74 & 3,62 & 0,92 & 0,55 & 0,76 & 0,51 & 1,22 & 1,91 & 0,57 & 0,64 \\
\hline 2 & Manufacturing & 1,08 & 0,86 & 0,67 & 1,11 & 1,76 & 1,19 & 1,01 & 0,82 & 0,86 & 0,89 & 1,15 \\
\hline 3 & Construction & 1,24 & 0,89 & 0,86 & 0,86 & 0,77 & 0,53 & 0,81 & 0,49 & 0,90 & 1,40 & 1,45 \\
\hline 4 & $\begin{array}{l}\text { Trade, Hotel, } \\
\text { and Restaurant }\end{array}$ & 1,11 & 1,17 & 0,99 & 1,01 & 0,96 & 1,15 & 1,03 & 1,19 & 1,02 & 0,83 & 0,88 \\
\hline 5 & $\begin{array}{l}\text { Transportation } \\
\text { and Storage }\end{array}$ & 1,04 & 0,47 & 0,73 & 0,55 & 0,76 & 0,62 & 0,80 & 0,48 & 0,68 & 1,73 & 1,86 \\
\hline \multirow[t]{2}{*}{6} & $\begin{array}{l}\text { Accomodation } \\
\text { and Food } \\
\text { Service }\end{array}$ & & & & & & & & & & & \\
\hline & Activities & 0,80 & 0,93 & 0,76 & 0,89 & 0,88 & 0,87 & 1,11 & 1,01 & 1,03 & 1,22 & 0,84 \\
\hline 7 & $\begin{array}{l}\text { Information and } \\
\text { Communication } \\
\text { Financial and }\end{array}$ & 0,87 & 1,02 & 1,30 & 0,98 & 1,05 & 0,69 & 1,33 & 1,09 & 0,92 & 0,91 & 0,96 \\
\hline \multirow[t]{2}{*}{8} & Insurance & & & & & & & & & & & \\
\hline & $\begin{array}{l}\text { Activities } \\
\text { Real Estate }\end{array}$ & 1,08 & 0,77 & 0,72 & 0,93 & 0,58 & 0,63 & 0,74 & 0,60 & 1,15 & 1,42 & 1,60 \\
\hline 9 & Activities & 0,11 & 0,58 & 0,91 & 0,91 & 0,80 & 0,28 & 0,75 & 0,51 & 1,34 & 1,79 & 0,91 \\
\hline 10 & Bank Services & 0,52 & 0,45 & 0,56 & 0,54 & 0,63 & 0,76 & 0,53 & 0,58 & 0,51 & 2,24 & 0,64 \\
\hline \multirow[t]{2}{*}{12} & $\begin{array}{l}\text { Education } \\
\text { Human Health } \\
\text { and Social Work }\end{array}$ & 1,03 & 1,10 & 1,22 & 1,27 & 1,06 & 1,07 & 1,21 & 1,17 & 0,99 & 0,69 & 0,92 \\
\hline & $\begin{array}{l}\text { Activities } \\
\text { Other Services }\end{array}$ & 0,90 & 1,06 & 0,98 & 1,09 & 0,54 & 1,00 & 0,99 & 0,63 & 1,14 & 1,17 & 1,28 \\
\hline 13 & Activities & 0,82 & 0,91 & 0,99 & 0,85 & 1,06 & 1,00 & 0,77 & 0,89 & 0,91 & 1,24 & 1,03 \\
\hline
\end{tabular}

Source: Central Bureau of Statistics, Provinsi Jambi, 2017 
Table 5 Superior Sector Recap (LQ) Based on Manpower Absorption of Regency / City in Jambi Province Year 2016

\begin{tabular}{|c|c|c|c|c|c|c|c|c|c|c|c|c|}
\hline & \multirow[b]{2}{*}{ Industrial Origin } & \multicolumn{11}{|c|}{ Regency / City } \\
\hline & & Kerinci & Merangin & Sarolangun & $\begin{array}{c}\text { Batang } \\
\text { Hari }\end{array}$ & $\begin{array}{l}\text { Muaro } \\
\text { Jambi }\end{array}$ & $\begin{array}{c}\text { Tanjung } \\
\text { Jabung } \\
\text { Barat }\end{array}$ & $\begin{array}{c}\text { Tanjung } \\
\text { Jabung } \\
\text { Timur }\end{array}$ & Bungo & Tebo & $\begin{array}{l}\text { Kota } \\
\text { Jambi }\end{array}$ & $\begin{array}{l}\text { Kota } \\
\text { Sungai } \\
\text { Penuh }\end{array}$ \\
\hline A. & $\begin{array}{l}\text { Agriculture, Forestry } \\
\text { and Fishery }\end{array}$ & - & - & - & - & - & - & - & - & - & - & - \\
\hline B. & $\begin{array}{l}\text { Mining and } \\
\text { Quarrying }\end{array}$ & - & - & - & - & - & - & - & - & - & - & - \\
\hline C. & $\begin{array}{l}\text { Manufacturing } \\
\text { Industry }\end{array}$ & $\sqrt{ }$ & - & - & $\sqrt{ }$ & $\sqrt{ }$ & $\sqrt{ }$ & $\sqrt{ }$ & - & - & - & $\sqrt{ }$ \\
\hline $\begin{array}{l}\text { D. } \\
\text { E. }\end{array}$ & $\begin{array}{l}\text { Electricity and Gas } \\
\text { Water supply, } \\
\text { Sewerage, Waste }\end{array}$ & - & - & - & - & - & - & - & - & - & - & - \\
\hline & $\begin{array}{l}\text { Management and } \\
\text { Remediation } \\
\text { Activities }\end{array}$ & - & - & $\sqrt{ }$ & - & - & - & - & $\sqrt{ }$ & $\sqrt{ }$ & - & - \\
\hline F. & Construction & $\sqrt{ }$ & - & - & - & - & - & - & - & - & $\sqrt{ }$ & $\sqrt{ }$ \\
\hline G. & $\begin{array}{l}\text { Wholesale and Retail } \\
\text { Trade; Repair of } \\
\text { Motor Vehicles and } \\
\text { Motorcycles }\end{array}$ & $\sqrt{ }$ & $\sqrt{ }$ & - & $\sqrt{ }$ & - & $\sqrt{ }$ & $\sqrt{ }$ & $\sqrt{ }$ & $\sqrt{ }$ & - & $\sqrt{ }$ \\
\hline $\mathrm{H}$. & $\begin{array}{l}\text { Transportation and } \\
\text { Storage }\end{array}$ & $\sqrt{ }$ & - & - & - & - & - & - & - & - & $\sqrt{ }$ & - \\
\hline I. & $\begin{array}{l}\text { Accomodation and } \\
\text { Food Services } \\
\text { Activity }\end{array}$ & - & - & - & - & - & $\sqrt{ }$ & - & $\sqrt{ }$ & $\sqrt{ }$ & $\sqrt{ }$ & - \\
\hline J. & $\begin{array}{l}\text { Information and } \\
\text { Communication }\end{array}$ & - & $\sqrt{ }$ & $\sqrt{ }$ & - & $\sqrt{ }$ & $\sqrt{ }$ & - & - & $\sqrt{ }$ & - & - \\
\hline K. & $\begin{array}{l}\text { Financial Services } \\
\text { and Insurances }\end{array}$ & $\sqrt{ }$ & - & - & - & - & - & - & $\sqrt{ }$ & - & $\sqrt{ }$ & $\sqrt{ }$ \\
\hline L. & Real Estate & - & - & - & - & - & - & - & $\sqrt{ }$ & - & $\sqrt{ }$ & - \\
\hline $\begin{array}{l}\text { M, } \\
\text { N. }\end{array}$ & Business Activities & - & - & - & - & - & - & - & - & - & $\sqrt{ }$ & - \\
\hline $\mathrm{O}$ & $\begin{array}{l}\text { Public } \\
\text { Administration and } \\
\text { Defence; Compulsory } \\
\text { Social Security }\end{array}$ & - & - & - & - & - & - & - & - & - & - & - \\
\hline P. & Education & $\sqrt{ }$ & $\sqrt{ }$ & $\sqrt{ }$ & $\sqrt{ }$ & $\sqrt{ }$ & $\sqrt{ }$ & $\sqrt{ }$ & - & $\sqrt{ }$ & - & - \\
\hline Q. & $\begin{array}{l}\text { Human Health and } \\
\text { Social Work Activities }\end{array}$ & - & $\sqrt{ }$ & - & $\sqrt{ }$ & - & - & $\sqrt{ }$ & $\sqrt{ }$ & - & $\sqrt{ }$ & $\sqrt{ }$ \\
\hline $\begin{array}{c}\mathrm{R}, \mathrm{S}, \mathrm{T} \\
\mathrm{U}\end{array}$ & $\begin{array}{l}\text { Other Services } \\
\text { Activities }\end{array}$ & - & - & - & - & $\sqrt{ }$ & - & $\sqrt{ }$ & - & - & $\sqrt{ }$ & $\sqrt{ }$ \\
\hline
\end{tabular}

Source: Central Bureau of Statistics, Provinsi Jambi, 2017 
Table 6. Superior Sector Recap (LQ) Based on Production of Regency / City in Jambi Province Year $2011-2015$

\begin{tabular}{|c|c|c|c|c|c|c|c|c|c|c|c|c|}
\hline & \multirow[b]{2}{*}{ Industrial Origin } & \multicolumn{11}{|c|}{ Regency / City } \\
\hline & & Kerinci & Merangin & Sarolangun & $\begin{array}{c}\text { Batang } \\
\text { Hari }\end{array}$ & $\begin{array}{c}\text { Muaro } \\
\text { Jambi }\end{array}$ & $\begin{array}{c}\text { Tanjung } \\
\text { Jabung } \\
\text { Barat } \\
\end{array}$ & $\begin{array}{c}\text { Tanjung } \\
\text { Jabung } \\
\text { Timur } \\
\end{array}$ & Bungo & Tebo & $\begin{array}{c}\text { Kota } \\
\text { Jambi }\end{array}$ & $\begin{array}{c}\text { Kota } \\
\text { Sungai } \\
\text { Penuh }\end{array}$ \\
\hline A. & $\begin{array}{l}\text { Agriculture, } \\
\text { Forestry and } \\
\text { Fishery }\end{array}$ & $\sqrt{ }$ & $\sqrt{ }$ & - & $\sqrt{ }$ & $\sqrt{ }$ & - & - & - & $\sqrt{ }$ & - & - \\
\hline B. & $\begin{array}{l}\text { Mining and } \\
\text { Quarrying }\end{array}$ & - & - & $\sqrt{ }$ & - & - & $\sqrt{ }$ & $\sqrt{ }$ & $\sqrt{ }$ & - & - & - \\
\hline C. & $\begin{array}{l}\text { Manufacturing } \\
\text { Industry }\end{array}$ & - & - & - & $\sqrt{ }$ & $\sqrt{ }$ & $\sqrt{ }$ & - & - & - & $\sqrt{ }$ & - \\
\hline D. & $\begin{array}{l}\text { Electricity and } \\
\text { Gas }\end{array}$ & - & - & - & - & - & - & - & - & $\sqrt{ }$ & $\sqrt{ }$ & - \\
\hline E. & $\begin{array}{l}\text { Water supply, } \\
\text { Sewerage, } \\
\text { Waste } \\
\text { Management } \\
\text { and } \\
\text { Remediation } \\
\text { Activities }\end{array}$ & $\sqrt{ }$ & $\sqrt{ }$ & $\sqrt{ }$ & - & - & - & - & $\sqrt{ }$ & - & $\sqrt{ }$ & $\sqrt{ }$ \\
\hline $\begin{array}{l}\text { F. } \\
\text { G. }\end{array}$ & $\begin{array}{l}\text { Construction } \\
\text { Wholesale and } \\
\text { Retail Trade; } \\
\text { Repair of Motor } \\
\text { Vehicles and } \\
\text { Motorcycles }\end{array}$ & $\sqrt{ }$ & $\sqrt{ }$ & $\sqrt{ }$ & $\sqrt{ }$ & - & - & - & $\sqrt{ }$ & $\sqrt{ }$ & $\sqrt{ }$ & $\sqrt{ }$ \\
\hline $\mathrm{H}$. & $\begin{array}{l}\text { Transportation } \\
\text { and Storage }\end{array}$ & - & - & - & - & $\sqrt{ }$ & - & - & - & - & $\sqrt{ }$ & $\sqrt{ }$ \\
\hline I. & $\begin{array}{l}\text { Accomodation } \\
\text { and Food } \\
\text { Services } \\
\text { Activity }\end{array}$ & - & - & $\sqrt{ }$ & - & - & - & - & $\sqrt{ }$ & - & $\sqrt{ }$ & $\sqrt{ }$ \\
\hline $\mathrm{J}$. & $\begin{array}{l}\text { Information } \\
\text { and } \\
\text { Communication } \\
\text { Financial }\end{array}$ & $\sqrt{ }$ & $\sqrt{ }$ & $\sqrt{ }$ & - & - & - & - & $\sqrt{ }$ & $\sqrt{ }$ & $\sqrt{ }$ & $\sqrt{ }$ \\
\hline - & $\begin{array}{l}\text { Services and } \\
\text { Insurances }\end{array}$ & - & - & $\sqrt{ }$ & - & - & - & - & $\sqrt{ }$ & & $\sqrt{ }$ & $\sqrt{ }$ \\
\hline L. & Real Estate & $\sqrt{ }$ & $\sqrt{ }$ & - & - & - & - & - & $\sqrt{ }$ & - & $\sqrt{ }$ & $\sqrt{ }$ \\
\hline $\mathrm{M}, \mathrm{N}$. & $\begin{array}{l}\text { Business } \\
\text { Activities }\end{array}$ & - & - & - & - & $\sqrt{ }$ & $\sqrt{ }$ & - & - & - & $\sqrt{ }$ & $\sqrt{ }$ \\
\hline O. & $\begin{array}{l}\text { Public } \\
\text { Administration } \\
\text { and Defence; } \\
\text { Compulsory } \\
\text { Social Security }\end{array}$ & $\sqrt{ }$ & $\sqrt{ }$ & $\sqrt{ }$ & $\sqrt{ }$ & - & - & - & - & $\sqrt{ }$ & $\sqrt{ }$ & $\sqrt{ }$ \\
\hline P. & Education & $\sqrt{ }$ & $\sqrt{ }$ & & $\sqrt{ }$ & - & - & - & $\sqrt{ }$ & - & $\sqrt{ }$ & $\sqrt{ }$ \\
\hline Q. & $\begin{array}{l}\text { Human Health } \\
\text { and Social } \\
\text { Work Activities }\end{array}$ & $\sqrt{ }$ & $\sqrt{ }$ & $\sqrt{ }$ & $\sqrt{ }$ & - & - & - & - & - & $\sqrt{ }$ & $\sqrt{ }$ \\
\hline $\mathrm{R}, \mathrm{S}, \mathrm{T}, \mathrm{U}$ & $\begin{array}{l}\text { Other Services } \\
\text { Activities }\end{array}$ & $\sqrt{ }$ & $\sqrt{ }$ & $\sqrt{ }$ & $\sqrt{ }$ & $\sqrt{ }$ & - & - & - & $\sqrt{ }$ & - & $\sqrt{ }$ \\
\hline
\end{tabular}

Source: Central Bureau of Statistics, Provinsi Jambi, 2017 
D. Analysis of MSMEs Superior Commodity in Regency / City $\mathbf{n}$ Jambi Province Table 7. Superior Commodity Recap Based on Production (LQ and

\begin{tabular}{|c|c|c|c|c|c|c|c|c|c|c|c|c|}
\hline \multirow[b]{2}{*}{ No } & \multirow[b]{2}{*}{$\begin{array}{c}\text { Name of } \\
\text { commodity }\end{array}$} & \multicolumn{11}{|c|}{ Regency / City } \\
\hline & & Kerinci & Merangin & Sarolangun & $\begin{array}{c}\text { Batang } \\
\text { Hari }\end{array}$ & $\begin{array}{l}\text { Muaro } \\
\text { Jambi } \\
\end{array}$ & $\begin{array}{c}\text { Tanjung } \\
\text { Jabung } \\
\text { Barat }\end{array}$ & $\begin{array}{c}\text { Tanjung } \\
\text { Jabung } \\
\text { Timur }\end{array}$ & Bungo & Tebo & $\begin{array}{l}\text { Kota } \\
\text { Jambi }\end{array}$ & $\begin{array}{l}\text { Kota } \\
\text { Sunga } \\
\text { Penuh } \\
\end{array}$ \\
\hline 1 & $\begin{array}{l}\text { Wet Land } \\
\text { Paddy }\end{array}$ & $\sqrt{ }$ & $\sqrt{ }$ & - & - & - & - & $\sqrt{ }$ & - & - & - & $\sqrt{ }$ \\
\hline 2 & $\begin{array}{l}\text { Dry Land } \\
\text { Paddy }\end{array}$ & - & $\sqrt{ }$ & - & - & - & - & - & - & $\sqrt{ }$ & - & - \\
\hline 3 & Maize & $\sqrt{ }$ & $\sqrt{ }$ & - & - & $\sqrt{ }$ & - & $\sqrt{ }$ & - & - & - & - \\
\hline 4 & Soybean & - & - & - & - & - & - & - & $\sqrt{ }$ & $\sqrt{ }$ & - & - \\
\hline 5 & Peanuts & $\sqrt{ }$ & $\sqrt{ }$ & - & - & - & - & - & - & $\sqrt{ }$ & - & - \\
\hline 6 & Mungbean & - & - & $\sqrt{ }$ & - & - & - & $\sqrt{ }$ & - & $\sqrt{ }$ & - & - \\
\hline 7 & Cassava & - & $\sqrt{ }$ & - & - & - & - & - & - & $\sqrt{ }$ & $\sqrt{ }$ & - \\
\hline 8 & Chili & $\sqrt{ }$ & - & - & - & - & - & - & - & - & - & - \\
\hline 9 & Potato & $\sqrt{ }$ & - & - & - & - & - & - & - & - & - & - \\
\hline 10 & Cabbage & $\sqrt{ }$ & - & - & - & - & - & - & - & - & - & - \\
\hline 11 & Petai & $\sqrt{ }$ & - & - & - & - & - & - & $\sqrt{ }$ & - & - & - \\
\hline 12 & Mango & - & - & - & $\sqrt{ }$ & - & - & - & $\sqrt{ }$ & - & $\sqrt{ }$ & - \\
\hline 13 & Durian & - & - & - & - & - & - & - & $\sqrt{ }$ & - & - & - \\
\hline 14 & Orange & - & - & - & - & - & - & - & $\sqrt{ }$ & - & - & - \\
\hline 15 & Karet & - & $\sqrt{ }$ & - & $\sqrt{ }$ & - & - & - & - & - & - & - \\
\hline 16 & Coconut & - & - & - & - & - & - & $\sqrt{ }$ & - & - & - & - \\
\hline 17 & $\begin{array}{l}\text { Robusta } \\
\text { Coffe }\end{array}$ & - & $\sqrt{ }$ & - & - & - & - & - & - & - & - & - \\
\hline 18 & Cocoa & - & - & - & - & $\sqrt{ }$ & - & $\sqrt{ }$ & - & - & - & - \\
\hline 19 & Areca Nut & - & - & - & - & - & - & $\sqrt{ }$ & - & - & - & - \\
\hline 20 & Cow & - & - & - & $\sqrt{ }$ & - & - & - & $\sqrt{ }$ & - & - & - \\
\hline 21 & Buffalo & - & - & $\sqrt{ }$ & $\sqrt{ }$ & - & - & - & $\sqrt{ }$ & - & - & $\sqrt{ }$ \\
\hline 22 & Goat & - & $\sqrt{ }$ & - & - & - & - & - & $\sqrt{ }$ & - & - & $\sqrt{ }$ \\
\hline 23 & Sheep & $\sqrt{ }$ & $\sqrt{ }$ & $\sqrt{ }$ & - & $\sqrt{ }$ & - & - & $\sqrt{ }$ & - & - & $\sqrt{ }$ \\
\hline 24 & Duck & - & - & - & - & - & - & - & $\sqrt{ }$ & - & - & $\sqrt{ }$ \\
\hline 25 & Broiler & - & - & - & - & - & - & - & $\sqrt{ }$ & - & $\sqrt{ }$ & $\sqrt{ }$ \\
\hline 26 & Layer & - & $\sqrt{ }$ & - & - & - & - & - & $\sqrt{ }$ & - & - & - \\
\hline 27 & $\begin{array}{l}\text { Marine } \\
\text { Fisheries }\end{array}$ & - & - & - & - & - & $\sqrt{ }$ & - & - & - & - & - \\
\hline 28 & $\begin{array}{l}\text { Terrestrial } \\
\text { Fisheries }\end{array}$ & - & - & $\sqrt{ }$ & - & - & - & $\sqrt{ }$ & - & - & $\sqrt{ }$ & - \\
\hline & Notes: & & & & & & & & & & & \\
\hline & & $\begin{array}{l}: \text { Regen } \\
: \text { Regen } \\
: \text { Regen } \\
\text { primary } \\
: \text { Crops } \\
: \text { Hortic } \\
: \text { Hortic } \\
: \text { Plantat } \\
: \text { Big cat } \\
: \text { Small } 1 \\
: \text { Poultry }\end{array}$ & $\begin{array}{l}y \text { in Superic } \\
y \text { that don't } \\
y \text { that don't } \\
\text { sector } \\
\text { dlture (Vege } \\
\text { dion } \\
\text { tle } \\
\text { ivestock }\end{array}$ & $\begin{array}{l}\text { Agricultura } \\
\text { Superior in } \\
\text { Superior in } t \\
\text { table Crops) } \\
\text { Plants) }\end{array}$ & $\begin{array}{l}\text { Sector } \\
\text { Agricult } \\
\text { ne }\end{array}$ & ural Sect & & & & & & \\
\hline
\end{tabular}




\section{Conclusions}

1. The development of MSMEs in the Regency / Municipality of Jambi Province during the period 2010-2015 shows an increasing trend. The average value of production grew by $69.47 \%$, credit by $3.24 \%$, total business by $4.84 \%$, employment by $10.47 \%$. While assets grew significantly by $144.76 \%$.

2. Factors that significantly affect the value of production are MSME and asset loans. This shows that capital and assets are the dominant factor in increasing production value. The number of business and labor does not significantly affect the value of MSMES production.

3. The result of $L Q$ analysis indicates that the sector which is the base sector (LQ>1) based on the use of labour varies between regencies / cities in Jambi Province. The major trade and retail sectors, car and motorcycle repairs and the education service sector is superior in almost all regencies. While based on agricultural production value, water procurement sector, waste management, construction sector, major trade and retail sector, information and communication sector, government administration, defense and compulsory social security sector, education service sector, health service sector and social activites and other services is the superior sector in almost all regencies in Jambi province. Kerinci, Merangin, Bungom regency, Jambi City, and Sungai Penuh City have more than eight superior sectors.

4. Analysis of superior commodities shows that:

- There are 28 superior commodities in from agriculture sector which is food crops, horticulture, plantation, animal husbandry, marine and fishery.

- Kerinci regency has superior commodities in lowland rice, corn, peanuts, chili, potato, cabbage, petai, and sheep.

- Merangin regency has commodities of paddy rice, paddy fields, corn, peanuts, cassava, rubber, robusta coffee, goats, sheep, laying hens.

- Tanjung Jabung Barat regency only has one superior commodity namely sea fishery. While Tanjung Jabung TInur has 7 superior commodities.

- Bungo regency has 12 superior commodities, Tebo Regency has 5 main commodities, Jambi City has 4 main commodities, Sungai Penuh City has 6 superior commodities, Muaro Jambi Regency has 3 main commodities, Sarolangun and Batanghari regencies have 4 main commodities each.

\section{Acknowledgments}

The corresponding author would like to acknowledge the funding support from the Ministry of Research, Technology and Higher Education, Republic of Indonesia research grant (Hibah RISTEKDIKTI).

\section{References}

Haeruman, H. (2000). Peningkatan Daya Saing MSMES untuk Mendukung Program PEL. Makalah Seminar Peningkatan Daya Saing, Graha Sucofindo, Jakarta.

Hafsah, M. J. (2004). Upaya Pengembangan Usaha Kecil dan Menengah (UKM). Infokop Nomor 25 Tahun XX, 2004. Deputi Bidang Pengkajian Sumberdaya UKMK. Kementerian Koperasi dan UKM.

Haryadi. (2009). Profil dan Permasalahan MSMES di Provinsi Jambi, dalam Kajian Pemanfaatan Bantuan Pemerintah Untuk Pengembangan MSMES. Fakultas Ekonomi, Universitas Jambi.

Kuncoro, M. (2007). Ekonomi Industri Indonesia, Menuju Negara Industri Baru 2030?. Penerbit ANDI Yogyakarta.

Maupa, H. (2004). Faktor-faktor yang menentukan pertumbuhan usaha kecil di sulawesi selatan. Disertasi Program Pascasarjana Unhas. Tidak dipublikasikan

Munizu, M. (2010). Pengaruh faktor-faktor eksternal dan internal terhadap kinerja usaha mikro dan kecil (UMK) di sulawesi selatan, Jurnal Manajemen dan Kewirausahaan 12, 33-41 
Nazir, M. (2005). Metode Penelitian. Ghalia Indonesia, Bogor.

Prasetyo,E. (2008). Peran usaha mikro kecil dan menengah (MSMES) dalam Kebijakan Penanggulangan Kemiskinan dan Pengangguran - AKMENIKA UPY, Volume 2, 2008.

Rejekiningsih, T.W. (2004). Mengukur besarnya peranan industri kecil dalam perekonomian di propinsi jawa tengah. Dinamika Pembangunan, 1(2). Jurnal Ilmiah, Jurusan IESP. FE UNDIP, Semarang.

Setyobudi, A. (2007). Peran serta bank indonesia dalam mengembangkan usaha mikro, dan menengah (MSMES). Buletin Hukum Perbankan dan Kebanksentralan, 5(2)

Sjafrizal. (2012). Ekonomi Wilayah dan Perkotaan. PT. Raja Grapindo Persada, Jakarta.

Tambunan, T. (2012). Usaha Mikro Kecil dan Menengah di Indonesia, Isu-Isu Penting. LP3ES, Jakarta.

Temtime, Z. T., and Pansiri,J (2004). Small business critical succes/failure factors in developing economies: some evidence from bostwana, American Journal of Applied Sciences 1, 18-25.

Zulfanetti. (2013). Kredit mikro, kecil dan menengah dan pengaruhnya terhadap nilai PDB dan penyerapan tenaga kerja MSMES serta kemiskinan di indonesia. Disertasi pada Program Pascasarjana. Universitas Padjadjaran, Bandung. Tidak Dipublikasikan. 